\title{
Hansenula alni, a New Heterothallic Species of Yeast from Exudates of Alder Trees
}

\author{
H. J. PHAFF, M. W. MILLER, AND MARY MIRANDA \\ Department of Food Science and Technology, University of California, Davis, California 95616
}

A novel member of the yeast genus Hansenula was recovered three times in 1968 from slime exudates of Alnus rubra in the state of Washington and in the province of British Columbia. The new species is named Hansenula alni because of its specific habitat in exudates of alder trees. This species occurs naturally in the haploid condition. Upon mixing of compatible mating types, conjugation occurs, and up to four hat-shaped spores are produced in zygotes or in diploid cells arising from zygotes. $H$. alni resembles $H$. canadensis (syn.: $H$. wingei) but differs from it in habitat and in ability to grow at $37^{\circ} \mathrm{C}$; furthermore, the deoxyribonucleic acid base composition of the former is approximately $1.5 \mathrm{~mol} \%$ higher than that of the latter. The type strain of $H$. alni is UCD-FS\&T 68-928A (= ATCC $36594=$ CBS 6986). Its compatible mating type is UCD-FS\&T $68-940$ $(=$ ATCC $36595=$ CBS 6987$)$.

Many tree species show the phenomenon of fluxing, the flowing of tree sap from a wound (4). Tree fluxes often persist for long periods of time, and the flowing sap becomes heavily colonized with yeasts and bacteria that are introduced by visiting insects such as drosophilae. The tree sap usually assumes a thick, slimy consistency (probably caused by microbial polysaccharide formation) and is therefore often referred to as a "slime flux."

In 1972 Phaff et al. (4) reported the isolation of three yeast strains, tentatively identified as yeast resembling Hansenula wingei Wickerham, from slime fluxes of Alnus rubra Bongard in the Pacific Northwest of North America. The three strains were isolated from widely separated trees and represented haploid, heterothallic mating types that sporulated well upon mixing of appropriate strains. Doubts about the identity of the three strains with $H$. wingei arose when it was found that the mating types of the isolates mated poorly with those of the heterothallic $H$. winge $i$ and no spores were evident (4). Furthermore, $H$. wingei occurs exclusively in insect frass of coniferous trees (mainly Picea), and the guanine-plus-cytosine $(\mathrm{G}+\mathrm{C})$ content of its nuclear deoxyribonucleic acid (DNA) was significantly lower than that of the strains from Alnus (2).

In the accompanying paper (2), we have shown that there is little complementarity between the DNA from $H$. wingei and that of the strains from alders. Consequently, we regard these strains as belonging to a new species of Hansenula, for which the name $H$. alni (L. noun Alnus generic name of the alder; L. gen. noun alni of alder) is proposed because its habitat is the exudate of alder trees.

\section{MATERIALS AND METHODS}

Samples of slime fluxes were collected during June and July of 1968 in various locations of Alaska, the Yukon Territory, British Columbia, Washington, Oregon, and California (4). The precise locations of the samples from Alnus which contained the new species of Hansenula are given in Table 1.

The samples were collected in new plastic vials or bags. Usually within 6 to $18 \mathrm{~h}$ after collection, a loopful of the slimy exudate was streaked directly on $5 \%$ malt agar acidified to $\mathrm{pH} 3.7$ with a precalculated amount of $1 \mathrm{~N} \mathrm{HCl}$. The plates were stored at ambient temperatures (ca. 15 to $25^{\circ} \mathrm{C}$ ) until colonies appeared. In spite of the low $\mathrm{pH}$, various numbers of bacterial colonies usually appeared together with those of yeasts. After 3 to 6 days, the plates were inspected with a dissecting microscope, and, for identification purposes, one yeast colony of each morphological type was brought into pure culture by two successive platings on malt agar. For further details on the collecting areas, see reference 4 .

Identification of the isolates involved characters determined by standard methods currently used in yeast taxonomy (8). DNA extraction and purification were done by a combination of the procedures of Marmur (3) and Bernardi et al. (1) as described by Price et al. (5). The G+C content of the DNA was calculated from buoyant density values in cesium chloride $(6,7)$ and was based on three separate determinations. Micrococcus lysodeikticus DNA, with a buoyant density of $1.7311 \mathrm{~g} / \mathrm{ml}$, was used as a reference. The buoyant density of the $M$. lysodeikticus DNA was derived from comparison with plasmid-free Escherichia coli K-12 DNA, whose buoyant density was taken to be $1.7100 \mathrm{~g} / \mathrm{ml}$. 


\section{RESULTS}

\section{Latin diagnosis of Hansenula alni sp. nov.}

In extracto malti post dies 3 cellulae ovoideae, (2.4-4.6) $\times(3.0-5.4) \mu \mathrm{m}$, singulae, binae, aut in catenis brevis; sedimentum, annulus et pellicula tenuis, non-nitida formantur. Post dies 21 pellicula crassa et sedimentum abundum.

Cultura in agaro malti post unem mensem $\left(18^{\circ} \mathrm{C}\right)$ cremea, mollis, nitida et glabra, convexa, margine piloso.

In agaro farinae Zea mays post dies 10 pseudomycelium, blastoconidia et blastosporae abundat.

Species heterothallica, haploideae. Oriuntur asci ex conjugatione inter cellulas sexus contrarii. Pileiformae ascosporae formantur ad 4 in quoque asco; asci rumpunter post 5-7 dies.

Fermentatio glucosi nullum.

Glucosum, maltosum, saccharum, cellobiosum, trehalosum (lente), melezitosum, amylum solubile (exigue), D-xylosum, L-rhamnosum, ethanolum, glycerolum, D-mannitolum, D-glucitolum, $\alpha$-methyl-D-glucosidum, salicinum, glucono- $\delta$-lactonum, kalium gluconatum (lente), acidum lacticum (exigue), acidum succinicum, et acidum citricum assimilantur at non D-galactosum, L-sorbosum, lactosum, melibiosum, raffinosum, inulinum, L-arabinosum, D-arabinosum, D-ribosum, methanolum, i-erythritolum, ribitolum, galactitolum, 2- et 5-ketogluconatum, meso-inositolum, nec glucosaminum.

Kalium nitricum, natrium nitrosum, et ethyl aminum assimilantur.

Ad crescentiam thiaminum et pyridoxinum necessariae sunt.

Crescere potest in $33^{\circ} \mathrm{C}$; nullum incrementum calore $35^{\circ} \mathrm{C}$. $\mathrm{G}+\mathrm{C}$ acidi deoxyribonucleati $=$ 41.8-42.0 mol\% (3 stirpes, vide tabulum 1).

Habitatio in exudati Alni rubrae.

Typus: Stirps UCD-FS\&T 68-928A (= CBS 6986) ex exudato $A$. rubrae Canadensis isolata est.

In collectione zymotica Centraalbureau voor Schimmelcultures, Delphi Batavorum sub no. 6986 deposita est.

Cultura auxiliaris UCS-FS\&T 68-940 (= CBS 6987) sexus alterius.

Description of $H$. alni: Growth in malt extract. After 3 days at $24^{\circ} \mathrm{C}$, the cells are ovoid and measure 2.4 to $4.6 \mu \mathrm{m}$ by 3.0 to $5.4 \mu \mathrm{m}$. They occur singly, in pairs, or in small clusters, occasionally in short chains. A thin ring and a small amount of sediment are present. After 3 weeks there is a thick, dull pellicle, a ring, and a heavy sediment.

Growth on malt agar. After 1 month, the streak culture is cream-colored to white, smooth, shiny, soft, and convex in cross-section; the border is fringed with pseudomycelia.

Dalmau plate culture on corn meal agar. After 9 days, a well-developed pseudomycelium with abundant blastospores and blastoconidia is present. True hyphae are lacking.

Formation of ascospores. Vegetative cells are haploid and heterothallic. Upon mixing of compatible strains, conjugation takes place; one of the two cells forming the zygote increases considerably in size (Fig. 1a to c). Ascospores usually develop in diploid cells arising from the zygote and rarely in the zygote itself. Two to four hat-shaped spores are produced per ascus (Fig. 1d to g); the asci gradually lyse and release the spores in groups of two, three, or four (Fig. 1e). Good sporulation was observed on malt agar after ca. 6 to 10 days. This yeast has not been isolated from nature in the diploid state.

\section{Other characteristics.}

Fermentation: Glucose is not fermented.

Assimilation of carbon compounds: D-Glucose, maltose, sucrose, cellobiose, trehalose (latent), melezitose, soluble starch (weak), D-xylose, Lrhamnose, ethanol, glycerol, D-mannitol, D-glucitol, $\alpha$-methyl-D-glucoside, salicin, glucono- $\delta$ lactone, potassium gluconate, DL-lactic acid (weak), succinic acid, and citric acid are assimilated. D-Galactose, L-sorbose, lactose, melibiose, raffinose, inulin, L-arabinose, D-arabinose, D-ribose, methanol, i-erythritol, ribitol, galactitol, 2and 5-ketogluconate, meso-inositol, glucosamine, and hexadecane are not assimilated.

Assimilation of nitrogen compounds: Potassium nitrate, +; sodium nitrite, +; ethyl amine, + .

Vitamin requirements: Thiamine and pyridoxine are essential for growth.

Growth on 50\% (wt/wt) glucose-yeast extract agar: Absent.

Growth on $10 \%$ (wt/vol) sodium chloride-yeast extract agar: Absent.

Maximum temperature for growth: $33^{\circ} \mathrm{C}$.

Acid formation on chalk agar: + (moderate).

Synthesis of starchlike compounds: Negative.

Gelatin liquefaction: Negative.

Casein hydrolysis: Negative.

Hydrolysis of urea: Urease test negative.

Lipolytic activity: Negative.

Growth in the presence of $0.1 \mathrm{mg}$ of cycloheximide per ml: Negative.

$\mathrm{G}+\mathrm{C}$ content of the nuclear DNA: 41.8 to 42.0 mol\% (range for three strains, see Table 1).

Type strain. The type strain, UCD-FS\&T 68-928A, was isolated from the slime flux of an alder tree (A. rubra Bongard) along highway 7, 10 miles (ca. $16.1 \mathrm{~km}$ ) west of Agassiz, British Columbia. The auxiliary strain giving the best sporulation (UCD-FS\&T 68-940, of opposite sex 
to $68-928 \mathrm{~A}$ ) was isolated from the slime flux of an alder tree 2 miles (ca. $3.2 \mathrm{~km}$ ) south of Parksville, Vancouver Island, British Columbia. Strains 68-928A and 68-940 have been deposited in the collection of the Yeast Division of the Centraalbureau voor Schimmelcultures in Delft, The Netherlands as CBS 6986 and 6987, respec- tively, and in the American Type Culture Collection, Rockville, Md., as ATCC 36594 and 36595 , respectively.

Sources. Table 1 lists the substrates, localities, mating types, and $\mathrm{G}+\mathrm{C}$ contents of the nuclear DNAs of the three strains. It appears that $A$. rubra is the host tree for $H$. alni.
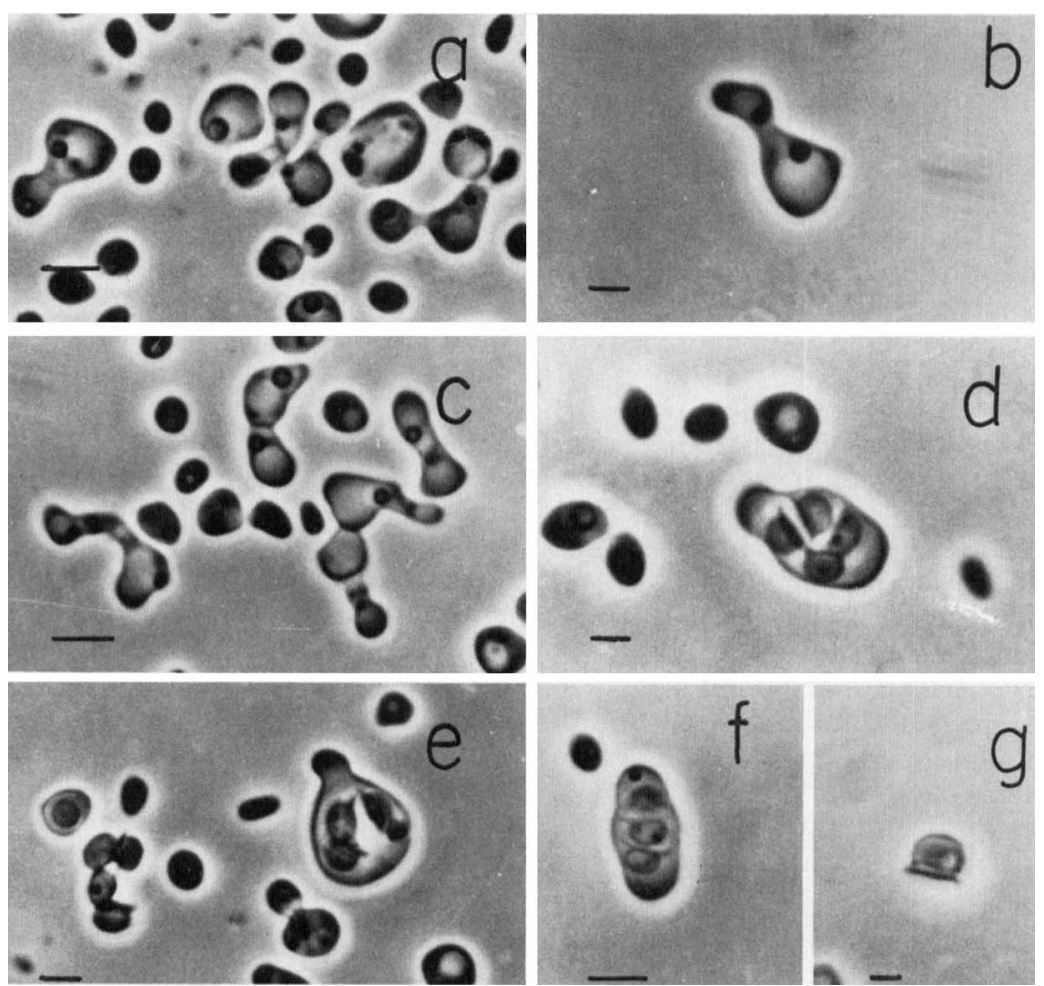

Fig. 1. (a) Mixture of H. alni mating types $68-928 A$ and 68-940 on malt agar after 2 days. Note zygote formation. (b) Single zygote; one of the conjugated cells has increased in size. (c) Variously shaped zygotes. ( $d$ and $f$ ) Asci containing four and three hat-shaped ascospores, respectively. (e) Ascus and four dehisced ascospores after 7 days on malt agar. (g) Lateral view of a single dehisced ascospore. Bar respresents $4 \mu \mathrm{m}$ in all cases.

TABLE 1. Localities, sources, mating types, and G+C contents of nuclear DNAs of isolates of Hansenula alni and phenotypically similar species of Hansenula

\begin{tabular}{|c|c|c|c|}
\hline $\begin{array}{l}\text { UCD-FS\& } T^{a} \text { strain desig- } \\
\text { nation }\end{array}$ & Habitat (substrate) & Mating type & $\begin{array}{c}\mathrm{G}+\mathrm{C} \text { of nuclear DNA } \\
\left(\mathrm{mol} \% \pm \mathrm{SD}^{t}\right)\end{array}$ \\
\hline Hansenula alni $68-928 \mathrm{~A}^{c}$ & Slime flux from $A \operatorname{lnus}{ }^{d}$ & $\alpha$ & $42.0 \pm 0.36$ \\
\hline H. alni $68-940 \ldots \ldots \ldots$ & Slime flux from $A \ln u s^{e}$ & $\mathbf{a}$ & $41.9 \pm 0.09$ \\
\hline H. alni $68-985$ & Slime flux from $A \ln u s^{f}$ & $\alpha$ & $41.8 \pm 0.25$ \\
\hline H. wingei $71-80^{c}$ & Frass from dead conifer & $\begin{array}{l}\text { Heterothallic } \\
\text { Diploid }\end{array}$ & $40.5 \pm 0.25$ \\
\hline H. canadensis $74-71^{c}$ & Frass from Pinus resinosa & $\begin{array}{l}\text { Homothallic } \\
\text { Diploid }\end{array}$ & $40.8 \pm 0.12$ \\
\hline
\end{tabular}

\footnotetext{
${ }^{a}$ UCD-FS\&T, University of California, Davis, Department of Food Science and Technology.

${ }^{b} \mathrm{SD}$, Standard deviation.

c Type strain.

${ }^{d}$ Located on highway 7,10 miles (ca $16.1 \mathrm{~km}$ ) west of Agassiz, British Columbia.

${ }^{e}$ Located 2 miles (ca. $3.2 \mathrm{~km}$ ) south of Parksville, Vancouver Island, British Columbia.

${ }^{f}$ Located along Hoh Road, Olympic National Park, state of Washington.
} 


\section{DISCUSSION}

When $H$. alni was first isolated (4), its colonies on malt agar were smooth and glistening. After storage on slants over a period of several years, a high proportion of the colonies had become mat and rugose, probably as the result of mutation. This phenomenon was minimal when the strains were stored in the freeze-dried state.

$H$. alni resembles $H$. canadensis in many of its phenotypic properties. It differs from that species in producing four, rather than two, spores per ascus; in occurring in nature as haploid, heterothallic cells rather than as diploid homothallic cells; in habitat (in exudates of a broad-leaf tree rather than in bark beetle frass of coniferous trees); and in that the $\mathrm{G}+\mathrm{C}$ content of its nuclear DNA is about $1.5 \mathrm{~mol} \%$ higher than that of $H$. canadensis (Table 1).

The three isolates of $H$. alni were initially regarded as possible strains of $H$. wingei (4). The molecular taxonomy studies reported in the accompanying paper (2) have shown that $H$. winge $i$ and $H$. canadensis share close to $80 \%$ of their DNA sequences, and therefore their names are synonyms. $H$. alni, on the other hand, showed very low DNA complementarity with these organisms as well as with others considered closely related to $H$. canadensis by Wickerham (9). $H$. alni thus constitutes a valid new species, and a description of it is provided in this paper.

Because of the many phenotypic properties in common between $H$. alni and $H$. canadensis, it may be postulated that $H$. wingei or $H$. canadensis is a progenitor of $H$. alni and that the latter diverged by adapting to a new habitat, the sap of a deciduous tree, $A$. rubra. It is not known whether $H$. alni occurs in nature in the diploid form. The three haploid strains isolated came from exudates of three different alder trees located at least $80 \mathrm{~km}$ apart (Table 1 ).

Aside from the difference in nuclear DNA base composition, the only phenotypic properties that can be used to differentiate $H$. alni from $H$. canadensis (syn.: $H$. winge $i$ ) are habitat and inability to grow at $37^{\circ} \mathrm{C} . \mathrm{H}$. alni occurs in exudates of alder trees, and its maximum temperature for growth is ca. $33^{\circ} \mathrm{C}$, whereas $H$. canadensis has been isolated only from beetleinfested coniferous trees and is capable of growing at $37^{\circ} \mathrm{C}$.

\section{ACKNOWLEDGMENTS}

We are greatly indebted to Nancy Krauter for her technical assistance in determining the DNA base compositions.

This research was supported, in part, by Public Health Service grant GM-16307-08 from the National Institute of General Medical Sciences to H. J. Phaff.

\section{REPRINT REQUESTS}

Address reprint requests to: H. J. Phaff, Department of Food Science and Technology, University of California, Davis, CA 95616 .

\section{LITERATURE CITED}

1. Bernardi, G., M. Foures, G. Piperno, and P. P. Slonimski. 1970. Mitochondrial DNAs from respiratory-sufficient and cytoplasmic respiratory-deficient mutants of yeast. J. Mol. Biol. 48:23-42.

2. Fuson, G. B., C. W. Price, and H. J. Phaff. 1979 Deoxyribonucleic acid sequence relatedness among some members of the yeast genus Hansenula. Int. $J$. Syst. Bacteriol. 29:64-69.

3. Marmur, J. 1961. A procedure for the isolation of DNA from microorganisms. J. Mol. Biol. 3:208-218.

4. Phaff, H. J., M. W. Miller, M. Yoneyama, and M. Soneda. 1972. A comparative study of the yeast florae associated with trees on the Japanese Islands and on the west coast of North America, p. 759-774. In G. Terui (ed.), Fermentation technology today. Society of Fermentation Technology, Osaka, Japan.

5. Price, C. W., G. B. Fuson, and H. J. Phaff. 1978. Genome comparison in yeast systematics: delimitation of species within the genera Schwanniomyces, Saccharomyces, Debaryomyces, and Pichia. Microbiol. Rev. 42:161-193.

6. Schildkraut, C. L., J. Marmur, and P. Doty. 1962. Determination of the base composition of deoxyribonucleic acid from its buoyant density in $\mathrm{CsCl}$. J. Mol. Biol. 4:430-433.

7. Szybalski, W. 1968. Use of cesium sulfate for equilibrium density gradient centrifugation. Methods Enzymol. 12B:330-360.

8. van der Walt, J. P. 1970. Criteria and methods used in classification, p. 34-113. In J. Lodder (ed.), The yeastsa taxonomic study. North Holland Publishing Co., Amsterdam.

9. Wickerham, L. J. 1970. Hansenula H. et P. Sydow, p. 226-315. In J. Lodder (ed.), The yeasts-a toxonomic study. North Holland Publishing Co., Amsterdam. 